\title{
Process Need Areas and Technology Adoption in Construction Site Management
}

\author{
"Aghaegbuna Obinna Ozumba', Udechukwu Ojiako², Winston \\ Shakantu ${ }^{3}$, Alasdair Marshall ${ }^{4}$ and Maxwell Chipulu ${ }^{4}$
}

Published online: 31 December 2019

To cite this article: Aghaegbuna Obinna Ozumba, Udechukwu Ojiako, Winston Shakantu, Alasdair Marshall and Maxwell Chipulu (2019). Process need areas and technology adoption in construction site management. Journal of Construction in Developing Countries, 24(2): 123-155. https://doi.org/10.21315/jcdc2019.24.2.6.

To link to this article: https://doi.org/10.21315/jcdc2019.24.2.6

\begin{abstract}
The study explores the areas of process need in construction site management and technology utilisation to address those needs within the construction industry. An exploratory case study was used, with a focus on process need areas that could be impacted by technology infusion. Results highlight the impact of human limitations on management performance and poor utilisation of available relevant technology in the presence of managerial lapses. Inherent limitations of case study strategy were experienced in the form of number of cases and achieving uniformity of features. Nevertheless, the cases provided rich cross-validating data. The article provides empirical insights about the possibility of construction site management benefiting from increased exploitation of technology to address management shortcomings. The article highlights the need to understand individual projects in terms of site management process needs and opportunities in recent information and communication technology (ICT) to address such need areas, by linking potential utility in technology to lapses in the management process of construction sites. The study provides a baseline understanding of relevant concepts of ICT adoption in site management. While considerable interest exists regarding technology use in construction, studies explicitly contextualised within process need areas in site management and with management-centred view remain sparse.
\end{abstract}

Keywords: Construction, IT/ICT, Management, Process, Site

\section{INTRODUCTION}

This study explores process need areas and technology infusion/utilisation in construction site management (CSM). Based on Tushman and Anderson (1986) and Rotolo, Hicks and Martin (2015), we define technology as "the range of devices, tools, equipment and supporting knowledge that has the capacity to serve as a mediator between inputs and outputs (process) and/or that create new products or services". As discussed hereunder, the study is based on the need for more insight on human limitations in site management (SM) and the use of technology to enhance such areas of weakness in the CSM process.

\footnotetext{
'University of the Witwatersrand, Johannesburg, SOUTH AFRICA

2University of Sharjah, University City Rd, Sharjah, UNITED ARAB EMIRATES

${ }^{3}$ Nelson Mandela University, University Way, Summerstrand, Port Elizabeth, SOUTH AFRICA

${ }^{4}$ University of Southampton, 12 University Rd, Southampton SO 17 1BJ, UNITED KINGDOM

*Corresponding author: obinna.ozumba@wits.ac.za
} 


\section{CSM AND THE NEED FOR TECHNOLOGY-BASED ENHANCEMENT}

Construction projects are described as complex management activities to implement (Bryde, Broquetas and Volm, 2013; Parvan, Rahmandad and Haghani, 2015) which includes CSM. Literature locates the origins of these complexities in the peculiar features of construction (Beardsworth et al., 1988; Chileshe et al., 2016). For example, it has large and unique products with limited standardisation. Construction also uses largely ephemeral and amorphous project teams (Davis, 2013; Parvan et al., 2015), of individual autonomy (Thomas, Riley and Messner, 2005). CSM is an aspect of management, which involves the day-to-day allocation, control and management of resources required for maximising output and minimising inefficiencies in construction (Thomas et al., 2005) which, partly depends on process variability and flexibility. CSM involves the amalgamation of resourcetransforming activities, which collectively generate finished outputs (Bresnen et al., 1984; Mustapha and Naoum, 1998; Mohamed and Anumba, 2006; Abbasian-Hosseini et al., 2014). It is arguable that the nature of the SM process would highlight human limitations in the live management of people, resources and site. It is also arguable that limitations in technological support, in the event of human limitations, would reflect on SM performance. Within this context, the study explores the dynamics of technology uptake and utilisation in the SM process, in relation to human limitations in management. South Africa is used as context for field data.

\section{CSM PROCESS NEED AREAS AND TECHNOLOGY INFUSION}

Historically CSM is known to suffer from capacity strain, which drives the demand for process enhancement (González et al., 2011). The complexities of construction and the nature of CSM, impose demands for process enhancement on construction SM (Ozumba and Shakantu, 2008; 2009). According to Green (1998), such demands were driven by the rhetoric of business process re-engineering (BPR), even though there were "doubts...regarding the originality and coherence of BPR" (p. 378).

Serpell and Alarcon (1998) however suggest an increasing emphasis on process enhancement, from the increasing focus of construction firms on improving project performance due to acknowledged technological limitations. González et al. (2011) suggest that construction industry's interest in process enhancement is driven by limited ability to protect its processes from negative effect of variability. With specific focus on CSM, the areas of constraints, or process weakness referred to, are categorised here as "process need areas"; drawing from (Ozumba, 2013) on "process needs areas", Ozumba and Shakantu (2008) on "process needs" and Ozumba and Shakantu (2009) on "need areas" respectively, in CSM. These are specific aspects of SM that have experienced shortcomings due to human limitations. It is proposed that adequate and appropriate infusion of technology into SM could enhance processes in these areas. Technology infusion, in the study, implies the "bringing in" or "steeping" of construction SM processes with technology; drawing from Bitner, Brown and Meuter (2000), Suh et al. (2010), Ojiako, Maguire and Chipulu (2012) and Ojiako et al. (2013) with perceived needs as a major driver. Thus, it is reasonable to expect that identifying process weakness may trigger enhanced infusion of technology.

The benefits of infusing technology into construction, have been extensively discussed in literature: Yang et al. (2007), Succar (2009), Grilo and Jardim-Goncalves 
(2010), Singh, Gu and Wang (2011), Becerik-Gerber, Ku and Jazizadeh (2012), Porwal and Hewage (2013), Nassar and AbouRizk (2014) and Ahn, Kwak and Suk (2015) for construction generally and Cheng and Teizer (2013), Kim et al. (2013) and Lin et al. (2014) for CSM.

However, CSM still suffers from capacity strain and process challenges, which may be alleviated through the infusion of technology, as substantiated in extant literature suggesting areas of intervention. A review of relevant extant literature on process need areas and related technology infusion in CSM is presented in Table 1.

Literature analysed here generally highlight processes that will benefit from the adoption/operationalisation of the respective technologies suggested. However, despite the appreciable amount of literature showcasing areas of intervention and possible benefits, there is scarcity of literature explicitly taking the on-site perspective and specifically addressing the SM process. There is scarcity of literature solving management problems with regard to technology infusion in CSM. Available literature is mostly focused on one individual or hybrid technological application which is then linked to an area of possible adoption and process improvement. Even more so, there are fewer relevant studies on developing countries of the world, including Africa. Such countries struggle with the demands of increased construction activity resulting from rapid urbanisation, demand for development and economic growth (Vegad, Madurwar and Ralegaonkar, 2014). Particularly for construction in developing countries, one of the main issues that have been highlighted in literature, is the need for effective leadership (Ofori and Toor, 2012). Leadership in construction involves management performance, which includes CSM. There is also evidence of emphasis on improvement of construction in developing countries, citing poor H\&S management, due to a stretching of SM capacity with the introduction of mechanisation (Idoro, 2011).

Considering relevant studies on construction in developing countries, there is evidence of various issues which emanate from CSM. Thomas and Sudhakumar (2014) cited frequency of revisions of design and the consequent re-work and timely access to drawings, from a study in India. Such factors fall under site information management and communication. Aje, Oladinrin and Nwaole (2016) highlighted material availability and labour productivity from a Nigerian study. Parthasarathy, Murugasan and Murugesan (2017) identified supervision as an area of weakness affecting manpower productivity. Issues under inadequate supervision were identified as interfacing of activities, lack of support equipment and lead time, while human factors ranked relatively highest. The process need areas mentioned here, fall largely under; general CSM, information management and communication and materials and H\&S management. A major process weakness is the lack of coordination of on-site activities. These areas of weakness can be adequately addressed through technology-based enhancement of CSM processes. To further buttress the argument for more technology infusion, Enegbuma et al. (2016) identified a significant correlation between improved processes and strategic technology adoption of BIM. From Vegad et al. (2014) the lack of technology was identified as the reason for poor CSM, because of obvious human weaknesses in manual coordination of on-site activities. Such human limitations were inevitable with increased scope, scale and rapidity of projects. It was found that over $50 \%$ of current project overhead could be addressed by exploiting existing technology. From the foregoing, it is arguable that studies on process need area enhancement in CSM are critical, especially for developing countries such as South Africa. 
Furthermore, in the context of South Africa as a developing country, there is some evidence in historical and recent literature, addressing technology infusion in construction, see Chege, Coetzee and Malachi (2001), Ibem and Laryea (2014), Venkatachalam (2015) and Ojiako et al. (2016). Such studies suggest the need for more uptake of technology. Similarly studies addressing technology infusion in CSM also suggest low occurrence (see Ozumba and Shakantu, 2012; 2013; 2014; 2017; 2018). However, just as extant literature presented in Table 1, these local studies do not provide the on-site perspective. Generally there is a gap in the articulation of on-site process need areas, through the lens of the various aspects of SM. There is a scarcity of such studies that are focused on understanding the dynamics of process need areas and relation to technology infusion. This gap is even more critical in the case of research on construction in developing countries.

Table 1. Process Need Areas and Related Technology Infusion in CSM from Literature Review

\begin{tabular}{|c|c|c|c|}
\hline Source & Technology & $\begin{array}{l}\text { Relevant Process Need } \\
\text { Area }\end{array}$ & CSM Aspect \\
\hline $\begin{array}{l}\text { Lee et al. } \\
(2017)\end{array}$ & $\begin{array}{l}\text { Building Information Modelling } \\
\text { (BIM) assisted labour productivity } \\
\text { monitoring system }\end{array}$ & $\begin{array}{l}\text { 1. Timely and accurate } \\
\text { 2. Measurement of } \\
\text { productivity }\end{array}$ & \multirow{2}{*}{$\begin{array}{l}\text { 1. Information } \\
\text { management and } \\
\text { communication } \\
\text { 2. Productivity } \\
\text { management }\end{array}$} \\
\hline $\begin{array}{l}\text { Akhavian and } \\
\text { Behzadan } \\
\text { (2016) }\end{array}$ & $\begin{array}{l}\text { Using smart sensors to sense } \\
\text { ubiquitous smartphones on site } \\
\text { and processing the information } \\
\text { with the use of machine learning } \\
\text { methodologies, to monitor } \\
\text { worker activity }\end{array}$ & $\begin{array}{l}\text { Monitoring and process } \\
\text { worker activity on site in } \\
\text { real time and following } \\
\text { the dynamic nature of } \\
\text { worker behaviour }\end{array}$ & \\
\hline $\begin{array}{l}\text { Zhong et al. } \\
\text { (2018) }\end{array}$ & $\begin{array}{l}\text { Integration of satellite and local } \\
\text { positioning systems, robotics } \\
\text { and real-time information } \\
\text { relay for compaction quality } \\
\text { monitoring for earth-rockfill dam } \\
\text { construction in deep narrow } \\
\text { valley }\end{array}$ & $\begin{array}{l}\text { Monitoring quality of } \\
\text { work in difficult site } \\
\text { situations }\end{array}$ & \\
\hline $\begin{array}{l}\text { Fang et al. } \\
(2018)\end{array}$ & $\begin{array}{l}\text { A computer vision-based } \\
\text { approach for safety harness } \\
\text { detection }\end{array}$ & $\begin{array}{l}\text { Monitoring of worker } \\
\text { compliance to the use } \\
\text { of safety harness while } \\
\text { working at heights. }\end{array}$ & $\begin{array}{l}\text { 1. Health and safety } \\
\text { (H\&S) management } \\
\text { 2. Information } \\
\text { management and }\end{array}$ \\
\hline $\begin{array}{l}\text { Dong et al. } \\
\text { (2018) }\end{array}$ & $\begin{array}{l}\text { Using an information process } \\
\text { system based on the concept } \\
\text { of radiation radius and intensity } \\
\text { to predict and detect the risk } \\
\text { of being struck in construction } \\
\text { site laydown area, via the } \\
\text { deployment of tracking systems }\end{array}$ & $\begin{array}{l}\text { Proactive struck-by risk } \\
\text { detection with worker } \\
\text { movement patterns } \\
\text { and movement } \\
\text { randomness }\end{array}$ & communication \\
\hline $\begin{array}{l}\text { Fang et al. } \\
(2018)\end{array}$ & $\begin{array}{l}\text { Use of a high precision, high } \\
\text { speed Faster R-CNN method } \\
\text { and far field surveillance videos } \\
\text { to detect construction workers' } \\
\text { non-hardhat-use }\end{array}$ & $\begin{array}{l}\text { Detecting non-hardhat- } \\
\text { use by workers }\end{array}$ & \\
\hline $\begin{array}{l}\text { Lee et al. } \\
(2017)\end{array}$ & Wearable sensors & $\begin{array}{l}\text { Monitoring of worker } \\
\text { physiological status }\end{array}$ & \\
\hline
\end{tabular}


Table 1. (continued)

\begin{tabular}{|c|c|c|c|}
\hline Source & Technology & $\begin{array}{l}\text { Relevant Process Need } \\
\text { Area }\end{array}$ & CSM Aspect \\
\hline $\begin{array}{l}\text { Wang et al. } \\
(2017)\end{array}$ & $\begin{array}{l}\text { Wireless and wearable } \\
\text { electroencephalography system } \\
\text { for monitoring attention and } \\
\text { vigilance }\end{array}$ & $\begin{array}{l}\text { Monitoring workers' } \\
\text { attention and vigilance } \\
\text { in construction activities }\end{array}$ & \\
\hline $\begin{array}{l}\text { Aryal, } \\
\text { Ghahramani } \\
\text { and Becerik- } \\
\text { Gerber } \\
\text { (2017) }\end{array}$ & $\begin{array}{l}\text { Real time monitoring of physical } \\
\text { fatigue in construction workers } \\
\text { using wearable sensors }\end{array}$ & $\begin{array}{l}\text { Real time monitoring of } \\
\text { changes in the heart } \\
\text { rate, thermoregulation } \\
\text { and electrical brain } \\
\text { activity }\end{array}$ & \\
\hline $\begin{array}{l}\text { Awolusia, Marksb } \\
\text { and Hallowell } \\
\text { (2018) }\end{array}$ & $\begin{array}{l}\text { Integrated wearable } \\
\text { technology for measuring } \\
\text { various construction safety } \\
\text { performance indicators }\end{array}$ & $\begin{array}{l}\text { Measurement of safety } \\
\text { performance indicators } \\
\text { on site }\end{array}$ & \\
\hline $\begin{array}{l}\text { Hwanga and } \\
\text { Leeb (2017) }\end{array}$ & $\begin{array}{l}\text { Wristband-type wearable health } \\
\text { devices to measure construction } \\
\text { workers' physical demands }\end{array}$ & $\begin{array}{l}\text { Measurement of worker } \\
\text { physical demands on in } \\
\text { real-time }\end{array}$ & \\
\hline $\begin{array}{l}\text { Mo et al. } \\
(2014)\end{array}$ & $\begin{array}{l}\text { Three-dimensional (3D) camera- } \\
\text { based robust bolt-hole detection } \\
\text { system for bolting cabin }\end{array}$ & $\begin{array}{l}\text { Bolt detection at } \\
\text { heights in steel frame } \\
\text { construction }\end{array}$ & \\
\hline $\begin{array}{l}\text { Cheng and } \\
\text { Teizer (2013) }\end{array}$ & $\begin{array}{l}\text { Real-time resource location data } \\
\text { collection and visualisation }\end{array}$ & $\begin{array}{l}\text { Construction safety, } \\
\text { and activity monitoring } \\
\text { information }\end{array}$ & \\
\hline $\begin{array}{l}\text { Kelm et al. } \\
\text { (2013) }\end{array}$ & $\begin{array}{l}\text { Mobile passive radio frequency } \\
\text { identification (RFID)-based, } \\
\text { automated and rapid control } \\
\text { of on-site personal protective } \\
\text { equipment (PPE) usage }\end{array}$ & $\begin{array}{l}\text { Real-time automatic } \\
\text { control of on-site PPE } \\
\text { usage compliance }\end{array}$ & \\
\hline $\begin{array}{l}\text { Guo et al. } \\
(2017)\end{array}$ & $\begin{array}{l}\text { Wearable-device-based } \\
\text { physical data measurement } \\
\text { systems for measuring worker } \\
\text { psychological status }\end{array}$ & $\begin{array}{l}\text { Monitoring worker } \\
\text { psychological status on } \\
\text { the job site }\end{array}$ & \\
\hline Yu et al. (2017) & $\begin{array}{l}\text { Use of an image-skeleton- } \\
\text { based system using parametric } \\
\text { information to monitor worker } \\
\text { behaviour }\end{array}$ & $\begin{array}{l}\text { Real-time identification } \\
\text { of construction workers' } \\
\text { unsafe behaviours }\end{array}$ & \\
\hline Teizer (2015) & $\begin{array}{l}\text { Wearable, wireless identification } \\
\text { sensing platform: Self-monitoring } \\
\text { alert and reporting technology } \\
\text { for hazard avoidance and } \\
\text { training }\end{array}$ & $\begin{array}{l}\text { Alerting individuals on } \\
\text { site when in potentially } \\
\text { hazardous proximity } \\
\text { conditions }\end{array}$ & \\
\hline Arslan (2014) & $\begin{array}{l}\text { Real-time environmental } \\
\text { monitoring, visualisation } \\
\text { and notification system for } \\
\text { construction H\&S management } \\
\text { using BIM and wireless } \\
\text { technology }\end{array}$ & $\begin{array}{l}\text { General H\&S } \\
\text { management }\end{array}$ & \\
\hline
\end{tabular}


Table 1. (continued)

\begin{tabular}{|c|c|c|c|}
\hline Source & Technology & $\begin{array}{l}\text { Relevant Process Need } \\
\text { Area }\end{array}$ & CSM Aspect \\
\hline $\begin{array}{l}\text { Wang et al. } \\
(2014)\end{array}$ & $\begin{array}{l}\text { Integrating augmented } \\
\text { reality (AR) with BIM for onsite } \\
\text { construction process controlling } \\
\text { for liquefied natural gas industry }\end{array}$ & $\begin{array}{l}\text { General CSM } \\
\text { constraints in control of } \\
\text { site processes }\end{array}$ & $\begin{array}{l}\text { 1. General CSM - } \\
\text { process control } \\
\text { 2. Information } \\
\text { management and }\end{array}$ \\
\hline $\begin{array}{l}\text { David et al. } \\
\text { (2014) }\end{array}$ & $\begin{array}{l}\text { The use of information } \\
\text { technology (IT)-backed } \\
\text { teleoperation, virtual guard and } \\
\text { control technologies to achieve } \\
\text { more efficient SM in tunnel } \\
\text { construction }\end{array}$ & $\begin{array}{l}\text { CSM in difficult sites } \\
\text { conditions such as } \\
\text { tunnels }\end{array}$ & $\begin{array}{l}\text { communication } \\
\text { 3. Resource } \\
\text { management }\end{array}$ \\
\hline $\begin{array}{l}\text { Han and } \\
\text { Golparvar-Fard } \\
\text { (2015) }\end{array}$ & $\begin{array}{l}\text { Appearance-based material } \\
\text { classification for monitoring of } \\
\text { operation-level construction } \\
\text { progress using 4D BIM and site } \\
\text { photo logs }\end{array}$ & $\begin{array}{l}\text { The difficulty in } \\
\text { detecting deviations } \\
\text { in construction work } \\
\text { progress }\end{array}$ & \\
\hline $\begin{array}{l}\text { Park and } \\
\text { Brilakis (2016) }\end{array}$ & $\begin{array}{l}\text { Integrating detection and } \\
\text { tracking systems to achieve a } \\
\text { higher level of worker position } \\
\text { and movement monitoring on } \\
\text { site }\end{array}$ & $\begin{array}{l}\text { Continuous localisation } \\
\text { of construction workers } \\
\text { via integration of } \\
\text { detection and tracking }\end{array}$ & \\
\hline $\begin{array}{l}\text { Kang et al. } \\
(2016)\end{array}$ & $\begin{array}{l}\text { Using BIM and a telepresence } \\
\text { management and site video } \\
\text { feed system to compare real } \\
\text { progress with schedule and in } \\
\text { real-time and make decisions } \\
\text { timely }\end{array}$ & $\begin{array}{l}\text { Real-time } \\
\text { management of } \\
\text { construction schedule }\end{array}$ & \\
\hline $\begin{array}{l}\text { Omar and } \\
\text { Nehdi (2016) }\end{array}$ & $\begin{array}{l}\text { Data acquisition technologies for } \\
\text { construction progress tracking; } \\
\text { especially IT, geo-spatial, 3D } \\
\text { imaging and augmented reality. }\end{array}$ & $\begin{array}{l}\text { Manual approaches to } \\
\text { on-site work progress } \\
\text { tracking }\end{array}$ & \\
\hline $\begin{array}{l}\text { Razavi, Montaser } \\
\text { and Moselhi } \\
\text { (2012) }\end{array}$ & $\begin{array}{l}\text { RFID deployment protocols for } \\
\text { indoor construction }\end{array}$ & $\begin{array}{l}\text { Difficulty in tracking } \\
\text { resources with satellite } \\
\text { based systems during } \\
\text { indoor construction } \\
\text { activities }\end{array}$ & \\
\hline $\begin{array}{l}\text { Braun et al. } \\
(2015)\end{array}$ & $\begin{array}{l}\text { Automated construction } \\
\text { progress monitoring using BIM- } \\
\text { based geometric constraints } \\
\text { and photogrammetric point } \\
\text { clouds }\end{array}$ & $\begin{array}{l}\text { Time consuming } \\
\text { manual approach } \\
\text { to onsite progress } \\
\text { monitoring }\end{array}$ & \\
\hline $\begin{array}{l}\text { Garcia, Arditi } \\
\text { and Le (2014) }\end{array}$ & $\begin{array}{l}\text { Construction progress } \\
\text { control (CPC) application for } \\
\text { smartphone, exploiting the } \\
\text { features of modern smartphones } \\
\text { and wireless communication }\end{array}$ & $\begin{array}{l}\text { The provision of } \\
\text { accurate information of } \\
\text { worksite progress. }\end{array}$ & \\
\hline
\end{tabular}

Therefore while acknowledging the relevance of existing literature, the motivation for the current study is that: the relevant body of knowledge that is currently more application-centred, requires management-centred studies and particularly with specific focus on the occurrence of process need areas in SM and technology infusion, using an on-site perspective. This would provide a complimentary body 
of information for a more balanced view. Hence, the intention here is to ascertain the extent to which technology utilisation may support process enhancement in CSM, from an on-site perspective. South Africa is used as context for field work. In doing so, the current study takes stock of the above-highlighted literature on: (1) technology infusion and the potential role of technology in construction, (2) challenges with SM and the interest in associated "process need areas" and (3) the scarcity of relevant empirical studies on technology infusion to CSM, in South Africa. Following Handfield and Melnyk (1998), Stuart et al. (2002) and Voss, Tsikriktsis and Frohlich (2002) who ask "what are the key issues?", the study research question (RQ) is "What process needs occur, which give rise to the need for technology adoption in construction site management?".

In order to understand process need areas, Green (1998), Serpell and Alarcon (1998), González et al. (2011) and Ozumba and Shakantu (2008; 2009; 2013) have been referenced elsewhere in the article and discussed. In order to understand technology infusion in the study, the following peculiarities of the study have been considered: CSM takes place in an organisational setting. It is a big process made up of processes. In addition, there is a specific scope in the study, using the onsite perspective. Furthermore, the study focuses on CSM constraints and technology infusion, leaving out influencing/moderating factors in technology occurrence, which may need to be explained from the lens of various theories and concepts. Technology infusion studies fall under the wide spectrum of technology transfer discourse. There are many theories, conceptual frameworks and models in extant literature, for exploring technology transfer. However in view of the peculiarities of the study, the following relevant theories and concepts are utilised:

1. Technology acceptance model (TAM) perspective (Lai, 2017; Shore et al., 2018; Taherdoost, 2018): It deals with the coupled effects of perceived usefulness and perceived ease of use which are moderated by the behavioural intention to adopt technology.

2. Ajzen and Fishbein's theory of reasoned action (TRA) (Özer and Yilmaz, 201 1; Ameen and Willis, 2018): It considers the rationality in individual behaviour, asserting that a number of factors are processed in the human mind prior to actions. Therefore behavioural intent largely governs the final outcome, while there is a measure of constraint from behaviour as an impact of other factors that are not necessarily internal.

3. The theory of planned behaviour (TPB) (Ajzen, 1991; 2011; Rosenthal, 2018): It highlights attitude towards the particular behaviour (technology adoption), subjective norm and perceived behavioural control. These inform behaviour, as moderated by intent.

4. The unified theory of acceptance and use of technology (UTAUT) (Ameen and Willis, 2018): A further development on the TAM concept and constructs. It uses a four usage determinants and four moderators of individual usage behaviour (performance expectancy moderated by gender, effort expectancy moderated by age, social influence moderated experience and facilitating conditions moderated by voluntariness).

5. The five-stage technology transfer model, which emphasises a process that ends with infusion (Cooper and Zmud, 1990; Ameen and Willis, 2018). Technology essentially goes through initiation, adoption, adaptation, acceptance and routinisation, before ending in continuous infusion. 
This pluralistic view compensates for the strictly singular focus on the management aspect of site in the study. The approach is used to underpin the collection and interpretation of data from field work, which are presented hereunder.

\section{RESEARCH DESIGN FOR THE STUDY}

The current article presents results from one stage of a larger multi-stage research project, which was conducted in South Africa, between 2009 and 2011 . For the current article, the epistemological perspective is that while appreciable knowledge exists in literature, the specific focus, perspective and context of the study remains to be explored, in light of existing knowledge. As such, following an analysis of the guiding research question and the data requirements for the study, a combined approach was adopted, at the methodological and methodical levels. From an analysis of the research question, the need to consider scenarios/ cases of SM process became evident. Sites constituted the main physical unit from which observations of the phenomena could be made. There was also the need to consider the management level at which the relevant activities were pitched. From descriptions provided in preceding sections of this article, CSM process is essentially at the operations management level, being operationalised within the physical construction site.

\section{Research Strategy}

Following the preceding analysis, it was determined that a combination of case study and operations research strategies was required for the study. Barratt, Choi and Li (2011) regarding case study research and Ketokivi and Choi, (2014) regarding operations research, are referenced as guidelines. Therefore a case study strategy that is focused on the operational context was adopted. The current study focuses on real-world empirical data (see Meredith et al., 1989; Flynn et al., 1990; Filippini, 1997). Following Barratt et al.'s (2011), a phenomenon is articulated, followed by literature review and an essentially inductive/exploratory research approach to fill a knowledge gap.

\section{Data requirements and units in the study}

With regard to the methodical approach, there was a need to consider the data requirements and the units in the study according to the following sequence: (1) unit of study (Where will the study be carried out for this research?: Construction sites), (2) unit of observation (What will be studied?: Site management) and (3) unit of analysis (What will be analysed?: CSM limitations/challenges and technology transfer to address such constraints).

The nature of data required was deemed to be mostly qualitative with minimal quantitative features for more robustness. However various aspects of the data required could be physically observed, read off documents and elicited from actors. Analysis of the data needs for the study, led to the conclusion that a combination of methods for data collection, within each case, would yield more comprehensive data sets for useful analysis. 
The unit of study comprises four construction sites located within the Johannesburg- Pretoria geographical axis of Gauteng Province, South Africa. The unit of observation was the SM process in each case. Mead (1938) suggests that the designated unit of analysis should not necessarily be an entity (such as, in this study, a construction company) but rather the behaviour of actors. Taking the verstehende sociological tradition (Weber, 1949) into consideration, the aim is to emphasise the importance and meaning of actions over the personality of actors. The focus ensures more practice-oriented relevance of the study (Kozinets, 2002). Hence, the precise unit of analysis is the actions (and challenges) of individual stakeholder actors on-site in relation to infusion of technology in selected aspects of CSM. From the review of possible interventions in CSM through technology infusion, the following aspects were chosen for scope and manageability of the study: health and safety, materials management and information management and communication.

The study was operationalised through documentary analysis, field observations and interviews. The aforementioned methods formed the multiple approaches to collecting data from each case. For the purpose of this article, consideration was given to the dating of the primary data collection (2011). Therefore an additional review of relevant literature (2012-2018), was performed in Table 1, to create additional basis for comparison and synthesis of results. The research model depicting the described research design is presented in Figure 1.
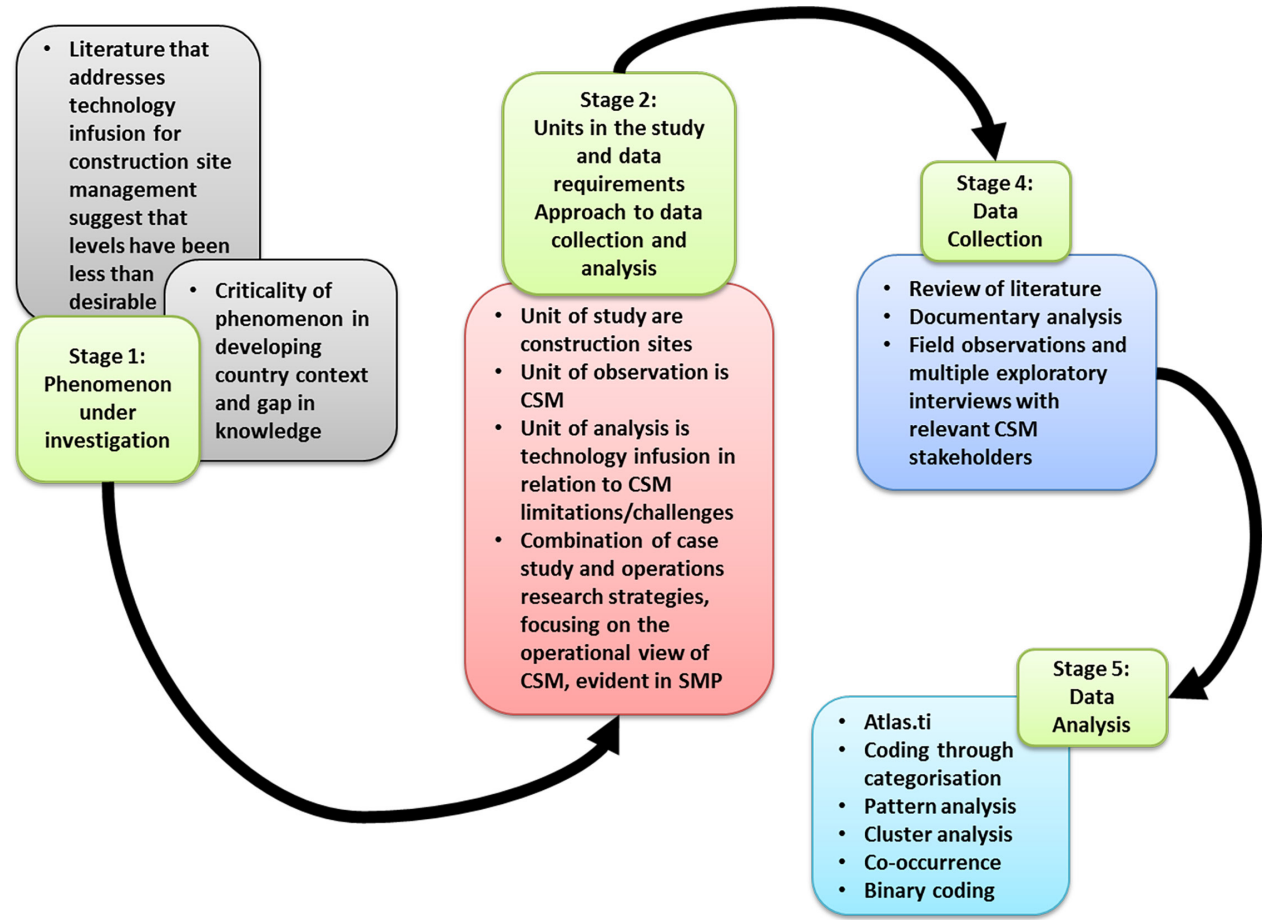

Figure 1. Research Model for the Study 
Field observation was the major avenue for collecting data. Informal interviews with SM personnel were used for explanatory and confirmatory purposes. Documentary analysis was used for information on SM structure and demographics. The specific instruments were (1) two site observation schedules, one each for lapses and technology infusion, respectively, with provision for recording responses to informal interview questions and (2) document content analysis schedule.

Field observation instruments were designed for passive observer administration. Challenges to SM were identified by observation of infringements and lapses in management, indicators of prevailing challenges to SM and from the responses of SM staff. Observations were also made of ICT use, or lack thereof. All observations focused on health and safety, materials management and information management and communication.

\section{Criteria for field observations}

Table 2 presents the major groups of lapses. Indicators for each variable were observed by identifying infringements in the area of each indicator, which continue to occur without detection/monitoring or intervention by SM personnel.

Table 2. List of Lapses Investigated on Study Sites

\begin{tabular}{llll}
\hline Category & $\begin{array}{l}\text { Sub-Category of } \\
\text { Lapses }\end{array}$ & Individual Lapses & $\begin{array}{c}\text { Maximum } \\
\text { Weight (Number } \\
\text { of Individual } \\
\text { Lapses) }\end{array}$ \\
\hline H\&S lapses & $\begin{array}{l}\text { Personal } \\
\text { protective } \\
\text { clothing (PPC) kits }\end{array}$ & $\begin{array}{l}\text { Incorrect PPE } \\
\text { Wrong use of PPE } \\
\text { No PPE at work }\end{array}$ & 3 \\
& Dropping tools and equipment \\
& Playing with tools and equipment & 3 \\
& Matching tools and equipment \\
& Smoking on the job \\
& Eating on the job \\
& Drinking on the job \\
& Drinking alcohol on the job \\
& Playing on the job \\
& ldling on the job \\
&
\end{tabular}


Table 2. (continued)

\begin{tabular}{|c|c|c|c|}
\hline Category & $\begin{array}{l}\text { Sub-Category of } \\
\text { Lapses }\end{array}$ & Individual Lapses & $\begin{array}{c}\text { Maximum } \\
\text { Weight (Number } \\
\text { of Individual } \\
\text { Lapses) }\end{array}$ \\
\hline & \multirow[t]{8}{*}{ Posture } & Bending body & \multirow[t]{8}{*}{8} \\
\hline & & Working below knee & \\
\hline & & Below ankle & \\
\hline & & Kneeling & \\
\hline & & Twisting body & \\
\hline & & Above shoulder/head & \\
\hline & & Reaching away & \\
\hline & & $\begin{array}{l}\text { Manual lifting heavy materials/ } \\
\text { objects }\end{array}$ & \\
\hline & \multirow{5}{*}{$\begin{array}{l}\text { Vehicular } \\
\text { equipment }\end{array}$} & Dangerous manoeuvring & \multirow[t]{5}{*}{3} \\
\hline & & $\begin{array}{l}\text { Operator using handheld } \\
\text { equipment }\end{array}$ & \\
\hline & & Operator self-directing & \\
\hline & & No remote tracking & \\
\hline & & No coalition control & \\
\hline \multirow{15}{*}{$\begin{array}{l}\text { Material } \\
\text { management } \\
\text { lapses }\end{array}$} & \multirow{5}{*}{$\begin{array}{l}\text { Material at } \\
\text { workforce }\end{array}$} & Unused materials & \multirow[t]{5}{*}{5} \\
\hline & & Unprotected materials & \\
\hline & & Weathered materials & \\
\hline & & Wasted/damaged materials & \\
\hline & & Material-related down-time & \\
\hline & \multirow{4}{*}{$\begin{array}{l}\text { Material at } \\
\text { staging area }\end{array}$} & Unused materials & \multirow[t]{4}{*}{4} \\
\hline & & Unprotected materials & \\
\hline & & Weathered materials & \\
\hline & & Wasted/damaged materials & \\
\hline & \multirow{4}{*}{$\begin{array}{l}\text { Material at } \\
\text { storage }\end{array}$} & Unused materials & \multirow[t]{4}{*}{4} \\
\hline & & Unprotected materials & \\
\hline & & Weathered materials & \\
\hline & & Wasted/damaged materials & \\
\hline & \multirow[t]{2}{*}{ Material in transit } & Unprotected materials & \multirow[t]{2}{*}{2} \\
\hline & & Wasted/damaged materials & \\
\hline
\end{tabular}


Table 2. (continued)

\begin{tabular}{|c|c|c|c|}
\hline Category & $\begin{array}{l}\text { Sub-Category of } \\
\text { Lapses }\end{array}$ & Individual Lapses & $\begin{array}{l}\text { Maximum } \\
\text { Weight (Number } \\
\text { of Individual } \\
\text { Lapses) }\end{array}$ \\
\hline \multirow{12}{*}{$\begin{array}{l}\text { Information } \\
\text { management } \\
\text { and } \\
\text { communication } \\
\text { lapses }\end{array}$} & \multirow[t]{3}{*}{$\begin{array}{l}\text { Communication } \\
\text { quality }\end{array}$} & $\begin{array}{l}\text { No technology-enabled } \\
\text { communication }\end{array}$ & \multirow[t]{3}{*}{3} \\
\hline & & No automated communication & \\
\hline & & Sole use of physical representation & \\
\hline & \multirow[t]{3}{*}{$\begin{array}{l}\text { Information } \\
\text { quality }\end{array}$} & $\begin{array}{l}\text { No real-time information integrity } \\
\text { checks }\end{array}$ & \multirow[t]{3}{*}{3} \\
\hline & & Incomplete information cycle & \\
\hline & & $\begin{array}{l}\text { No multimedia enabled } \\
\text { information }\end{array}$ & \\
\hline & \multirow[t]{6}{*}{ Real time lapse } & No real-time notification & \multirow[t]{6}{*}{6} \\
\hline & & No real-time detection & \\
\hline & & No real-time identification & \\
\hline & & No real-time directing & \\
\hline & & No real-time tracking & \\
\hline & & No real-time control & \\
\hline
\end{tabular}

Table 3 presents major categories and sub-categories for observations of technology usage at the sites. Field observations also took into consideration SM function and level of technology usage. In total, 34 technology types or sub-groups were listed under the categories.

Table 3. List of ICT and Automation Technologies Investigated on Study Sites

\begin{tabular}{llc}
\hline ICT Type & ICT Sub-Group & $\begin{array}{c}\text { Maximum } \\
\text { Weight } \\
\text { (Number of ICT } \\
\text { Sub-Groups) }\end{array}$ \\
\hline Mobile-handheld & Laptops & 5 \\
& Smart/cell phones & Tablet personal computer (PC) \\
& Digital pen & 4 \\
Geo-surveillance & Digital assistants and handheld computers & \\
instruments & Global Positioning System (GPS) & \\
& Surveillance & \\
& Laser range finder/measurer & \\
& Digital surveying instruments & \\
\hline
\end{tabular}


Table 3. (continued)

\begin{tabular}{|c|c|c|}
\hline ICT Type & ICT Sub-Group & $\begin{array}{c}\text { Maximum } \\
\text { Weight } \\
\text { (Number of ICT } \\
\text { Sub-Groups) }\end{array}$ \\
\hline \multirow{7}{*}{$\begin{array}{l}\text { Sensors and } \\
\text { scanners }\end{array}$} & Alcohol breath tester & \multirow[t]{7}{*}{8} \\
\hline & Barcode scanner & \\
\hline & Biometric systems & \\
\hline & Circuit tracers & \\
\hline & Thermal imaging scanner & \\
\hline & Concrete scanners & \\
\hline & Drug saliva tester & \\
\hline \multirow{9}{*}{$\begin{array}{l}\text { Hybrid } \\
\text { technologies }\end{array}$} & Machine control & \multirow[t]{9}{*}{9} \\
\hline & Virtual reality (VR) & \\
\hline & AR & \\
\hline & Video conferencing & \\
\hline & Telepresence & \\
\hline & Four-dimensional computer-aided design (4D CAD) & \\
\hline & Five-dimensional computer-aided design (5D CAD) & \\
\hline & $\mathrm{nD}$ modelling & \\
\hline & BIM & \\
\hline \multirow{7}{*}{$\begin{array}{l}\text { Wireless applications } \\
\text { and services }\end{array}$} & Company web portals & \multirow[t]{7}{*}{8} \\
\hline & Electronic data management system (EDMS) & \\
\hline & Virtual private networks (VPN) & \\
\hline & Cloud computing & \\
\hline & $\begin{array}{l}\text { Wireless network: Wireless local area network } \\
\text { (WLAN)/Wi-Fi }\end{array}$ & \\
\hline & Wireless internet & \\
\hline & $\begin{array}{l}\text { Site intranet } \\
\text { Project extranet }\end{array}$ & \\
\hline
\end{tabular}

Drawing upon (Booth and Lee, 1995; Rajendran et al., 2013; Aljassmi and Han, 2014; Love et al., 2014), the term "lapses", is used for management shortcomings, in the supervisory/monitoring role of the main players responsible for overseeing SM. These "lapses" often result in negative CSM practices and infringements. Occasionally, they may result in non-compliance with safety regulations. These lapses are due to limitations in human capacity to ally, direct, track, monitor and control the activities of operatives and movement and utilisation of resources on site - thus the term "process need areas". Alleviating such lapses may not be feasible without the infusion of technology thus the term "technology-based process enhancement". 


\section{The case study}

Visits to study sites were performed within three days in 2011 . Relevant items and their sub-classifications were recorded as they were observed. Each site was divided into two sections: site office and site grounds or production zone. The sequence of data collection was as follows: (1) document study and analysis of the CSM structure and site demographics, (2) observations of site office and (3) observations of site grounds (production zone). Site office investigations focused on occurrence of technology usage by senior SM and office support staff. Site grounds observations comprised a static view of each site for an overview, followed by a walkabout. The walkabout sequence was as follows: (1) entrance to site production zone, (2) site storage, (3) materials staging areas and (4) work-faces. The procedure was repeated on several occasions, considering concentration of labour and materials, circulation routes on site grounds, plant and heavy equipment, activities and movements of operatives and supervisors and technology utilisation among field officers or supervisors. Figure 2 depicts the implementation of the data collection plan. The pre-structured lists of CSM lapses and relevant items of technology observed in the study were determined from the review of relevant literature and preliminary studies in the local context.

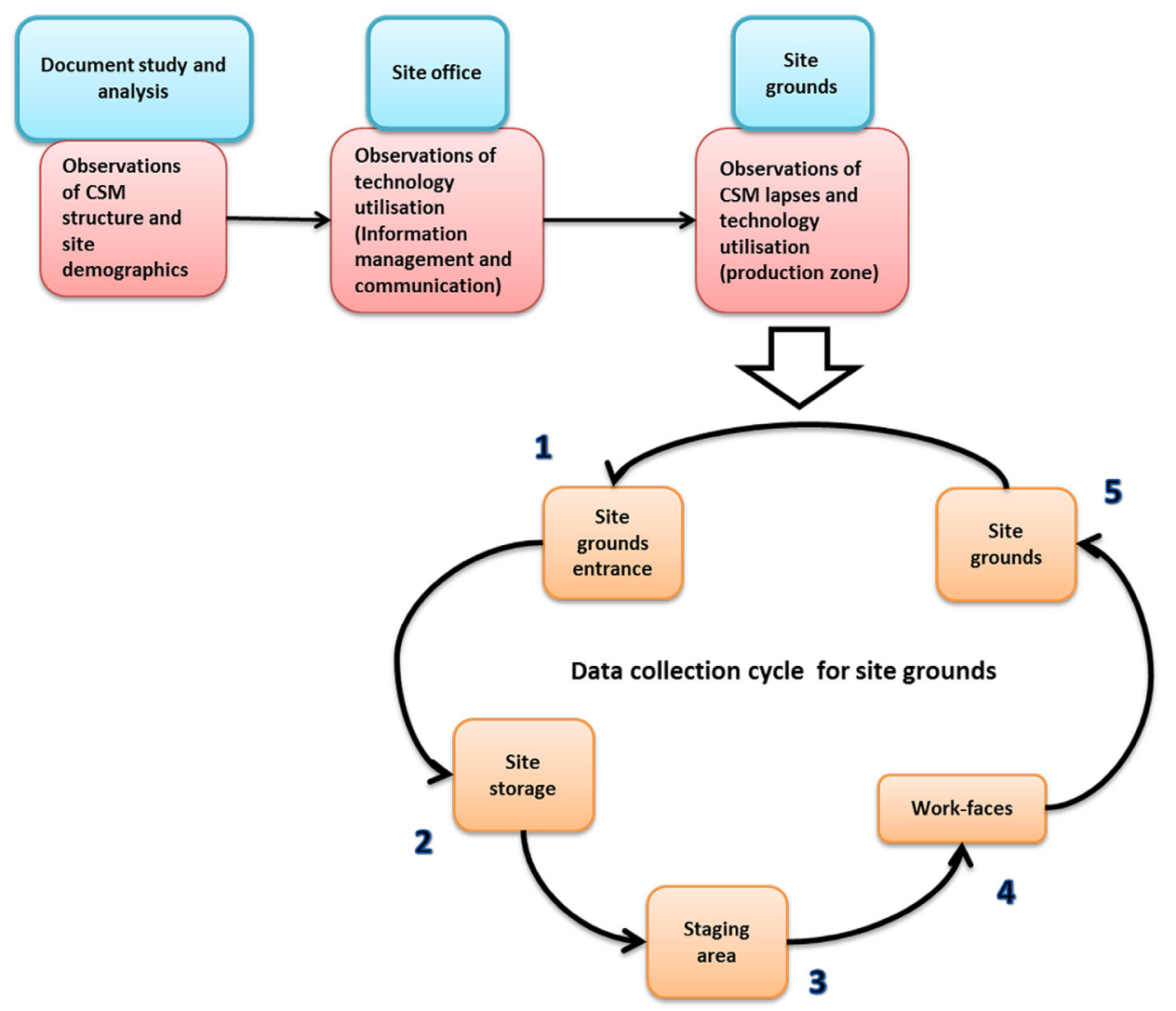

Figure 2. Data Collection Sequence and Details for the Study 


\section{The cases}

The four case sites, located within the geographical delimitation of the JohannesburgPretoria axis, which represents the business/economic capital of South Africa, were purposively selected. The number of cases is justified with reference to Eisenhardt (1989) who suggests that, there is no ideal number of case studies, while stating that "a number between four and ten cases usually works well" (p. 545). He notes that more than 10 cases would create difficulties with volume and complexity of data, while studies with less than four cases would be unconvincing.

All case sites as profiled in Table 4, were characterised as involving construction works contracts legally classified as "Civil Engineering" by the statutory Construction Industry Development Board (CIDB) of South Africa. The four purposively selected case sites were managed by CIDB Grade 5 to 9 level contractors. These are projects with a tender value from ZAR 6.5 million (Grade 5) to no limit (but over ZAR 130 million) (CIDB, 2015). The range of contractors would most likely have the financial capability and size to engage technology, as supported by literature that links firms' capabilities to technology adoption (Chae, Koh and Prybutok, 2014) and willingness to infuse technology in service (Kindström, Kowalkowski and Sandberg, 2013; Kowalkowski, Kindström and Gebaver, 2013).

Table 4. General Demographics of Study Sites

\begin{tabular}{lcccc}
\hline Site Variables & Site A & Site B & Site C & Site D \\
\hline Project-type & Multi-storey & Multi-storey & Multi-storey & Multi-storey \\
\hline Value & ZAR 100+ M & ZAR 21 M & ZAR 34.3 M & ZAR 90 M \\
Site-size (sq.m) & 2,500 & 2,100 & 2,000 & 6,520 \\
Males & 94 & 38 & 51 & 152 \\
Females & 7 & 3 & 1 & 63 \\
Age (18-25 years old) & 11 & - & 7 & 12 \\
Age (26-35 years old) & 38 & 21 & 8 & 193 \\
Age (36-45 years old) & 44 & 20 & 8 & 10 \\
Age (46-55 years old) & 8 & - & 6 & - \\
Age (56 years old and above) & - & - & 1 & - \\
Sub-contractors & 8 & 4 & 5 & 9 \\
Trades & 9 & 6 & 8 & 10 \\
Specialists & - & 6 & 8 & 4 \\
Site office & 7 & 3 & 2 & 6 \\
Field supervisors & 8 & 6 & 4 & 12 \\
H\&S officers & 12 & 1 & 8 & 7 \\
Languages spoken & 5 & 3 & 6 & 5 \\
\hline
\end{tabular}




\section{DATA ANALYSIS AND RESULTS}

Data was collated in Microsoft Excel, while structuring of text and further analysis was performed in ATLAS.ti (Miles and Huberman, 1984), for adequate rigour and transparency (Kvale, 1996). Following Easterby-Smith (2011), themes emergent from coding undertaken through categorisation, were suggestive of possible patterns and relationships. Results are presented as contextual descriptions, analytical findings, thematic discussions, highlights of patterns and suggested relationships. A complementary deductive process was also conducted to provide more robustness and basis for cross-validation of results.

\section{General Observations}

The SM structure/organogram for the four sites highlight the needs assessment undertaken and the provisions made for efficient and effective management of each site. Such provisions were viewed in relation to observed roles played by the CSM in the areas of interest for the study, which helped to identify areas of possible strains to SM capacity. At Site A, the management structure had two levels between site manager and operatives, which were made up of general foremen and supervisors. There were provisions for a range of individual roles; however, only the main H\&S officer and three field officers shared the workload. Site B had a site manager who worked with two supervisors. The senior site manager and H\&S officer were not regularly on site. Site $C$ had a site agent working with two supervisors, two H\&S officers and one store manager. The two H\&S representatives managed (20-30) construction workers/staff at any time. The main storeman undertook site materials management, supervised two staff members and secured storage rooms and storage areas at the site's main entrance. On Site D (the largest), the management structure included more specialists. The site agent managed the site through a site quantity surveyor, chief H\&S officer and site engineer, who in turn oversaw field officers and foremen. The H\&S field officers managed approximately 50 construction workers/staff.

\section{Lapses and Technology Occurrence}

From observations on all sites, the predominantly occurring lapses fall under the information management and communication category. They are lack of realtime capacity and low quality of information and its communication. None of the sites could support real-time monitoring. Most observed lapses also fall under H\&S category, particularly poor monitoring of unhealthy working postures. The least occurring lapses involved materials management, with most observations related to site storage. There were appreciable similarities in the occurrence of lapses on all four sites.

Infusion of technology was minimal on all four sites. Available technology was for basic usage in each instance. Overall infusion of technology within any of the study sites did not amount to half of pre-determined sub-categories in Table 3. Communication was primarily paper-based and through physical representation. The five predetermined major technology groups in Table 3 have 34 identified specific sub-groups of technology items. Each major technology group (e.g., mobile-handheld) was weighted by the number of its technology sub-groups. 
All items of technology observed were recorded under their relevant sub-groups. Thus, observations of technology could be described as a proportion of the sum of weightings (34) for technology in the predetermined list. The highest occurrence of technology infusion (12/34) was observed at Site C. This was followed by Sites A, $D$ and $B$, which recorded fewer observations, in that order. The "Mobile hand-held devices" category had the highest aggregated occurrence (9/20) for the study, while the "Geographic and surveillance technologies" category had the highest occurrence (3/4) for any site. Similarly, the highest observation of "Sensors and scanners" was 4/8, while the highest occurrence of "Wireless technologies" was 3/8. Items under the "Hybrid technology" category were not observed on any of the sites visited. None of the sites recorded more than $50 \%$ occurrence of technology infusion.

\section{Infusion of Technology and Utilisation}

At Site A, communication was facilitated by wireless internet, as opposed to site intranet. Each laptop utilised individual wireless modems linked to commercial service providers; nevertheless, significant paper-based communication was observed. Despite cell phone use on site, communication depended heavily on human relays. SM personnel were observed moving back and forth between site office and the construction zone. There was lack of remote visualisation and control, real-time management and dynamic inventory on site. Requests for materials were registered automatically at the company headquarters, only after manual capture and verification on site. Workers were also observed in many non-compliant positions without visible intervention by SM. There were instances of operatives working around the edge of decks without harnesses, squatting precariously close to a one-storey-deep opening and idling while leaning backwards towards a thin railing facing the same opening. Although a supervisor was observed standing close by, he could not address the issue because it occurred behind him. Such blind spots occurred frequently. In addition, two available storage areas, did not have automated communication with the site office, or production zone. Although sensitive material and equipment were kept in store, visual recognition and familiarity with store managers were the only conditions for identification and checking-out of items. Directing of mobile and fixed cranes was performed via visual and aural recognition. A designated rigger with colour-coded hardhat directed the crane operator, by relying on the strength of his voice above the noise of machinery and clarity of sign language through the airborne dust on site.

Although the least in size, Site B seemed to experience most lapses in SM. In terms of technology infusion, interview responses indicated that laptops were used by senior site managers during site visits. Usage was, however, restricted to checking databases and external communications and the company's virtual private network and wireless internet. Communication around the site was completely manual, while cell phones were used for external communication. CSM personnel physically walked around site and shouted, to communicate with workers. Workers were also observed standing on scaffolding above ground level, without harnesses and sometimes with supervisors. In one instance, a supervisor did not have a hard hat on. Such non-compliance occurred more in remote parts of the site. There were observations of operatives handing over tools and substances overhead and below ankles and manually lifting heavy objects. In addition, the site vehicle operator had instructions shouted at him and then self-directed himself. 
Delivery of materials, as observed, resulted in appreciable downtime due to a lack of necessary logistics communication required for Just-in-Time (JIT) delivery of materials. Delivery personnel had to park their truck off-site and communicate with the contract manager via cell phone, for purposes of inventory and offloading. Traffic on the road was interrupted by the parked truck during the downtime.

At Site $C$, cell phones were used for communication between site agent, supervisors and H\&S officers. However, there was no real-time monitoring or system. H\&S officers did not use cell phones to communicate with each other. The site agent also relied on the supervisors to do their job well and to forward details of site activities, which arrived after the fact, in the form of two site reports per day. There were cases of materials dropping from heights due to poor storage and tools being dropped from heights by construction workers. In a particular case, poor miscommunication between loaders at ground level and off-loaders on the deck above resulted in the dropping and breaking of bricks. The conveyor hauling the bricks upwards lacked dynamic control and the loaders could not control the belt once it was started. The rising pile of rubble at the ground level attested to the wastage. In addition, site materials management was performed by one main store man who supervised and secured storage rooms and the storage areas at the site main entrance. The open air storage and laydown space was administered by two persons. Supply to staging areas from the open storage area was continuous throughout the day. There was, however, no automated inventory management in the system of delivery. Visual recognition was used to assess material needs for various staging areas. In addition, responsibility for security of the storage area was also assigned to the same store personnel, which led to occasional blind spot during materials delivery and checks.

At Site D, available cell phones, laptops and desktop computers were used mostly for communicating with the project management office. Site materials storage occupied appreciable space, both inside and outside the production zone. However, there was no technology-enabled management of materials on site. Useful information for site materials management reached SM after the fact, through reports at the close of work. Utilisation of available technologies was appreciably below embodied potential in each case. Communication was mainly by shouting, in combination with gesticulation. Being a large site, CSM was obviously strained due to lack of ubiquity and pervasiveness. While cell phones were used on site, H\&S officers communicated in person with each other and SM. Vehicular operators directed themselves around the site for the most part, with minimal monitoring. Similarly, there were unscheduled down times, when workers idled at the workface, sometimes above ground level. From spot interviews on site an incident was reported, which resulted in the loss of material, work hours and money for the contracting company. The causative factors were lack of real-time and remote access to site-based project information and limited information collaboration. Although the costs were borne by the main contractor, the information system had not been improved by the time of this study.

\section{Further Analysis: Quantised Data from Site Observations}

In order to explore the emergent patterns further and gauge the results of the preceding qualitative analysis, a complementary analysis of quantised/quantified qualitative data was used. The case study data was coded into numerical standards for quantitative analysis (Grix, 2004: 121-122). Binary coding was used for 
quantisation of data, where ( 1 = observed, 0 = not observed). Quantification was applied to observations of lapses and utilisation of relevant technologies in CSM. The objective was to generate rankings for both sets of variables, in order to; firstly infer the severity of occurrence and prevalence of lapses regarding the lack of technology infusion, on site; and secondly to correlate the respective occurrence of technology infusion/adoption and occurrence of lapses. The analysis provides insight into the likelihood of relationships between occurrence of lapses and lack of technology infusion on sites. The possibility of associations between particular lapses and the lack of infusion of certain technology types was also highlighted. It was also possible to highlight and further explore apparent anomalies, where persistent occurrence of management lapses existed alongside infusion of relevant technology.

With reference to Tables 2 and 3, three levels of data were utilised - "Main Category", "Sub-Category" and "Indicator Level/Individual Items of Observation". The number of indicators was used to weight each sub-category and the quantised version was used to correlate the occurrence of managerial shortcomings (lapses) and lack of technology infusion at each of the four case sites. The results influence recommendations, which are further explored by relating them to the preceding analysis of site observations. Through this procedure, it was also possible to acquire a better understanding of the frequency and similarity of shortcomings (lapses) and therefore the need for technology. By considering the generated ranking, areas of possible severity in terms of occurrence for these identified shortcomings (lapses) could be inferred. Furthermore, possible associations with the lack of certain technology groups could be more strongly highlighted. Example of the calculation for the weighting system in Table 5 is as follows:

Under lapses (shortcomings), in the area of H\&S management;

Sub-category "PPE" = Three individual lapses (Incorrect PPE; Wrong use of PPE; No PPE at work).

Therefore maximum weighting for PPE according to the pre-structured list $=3$.

It was then possible to weight the observed occurrence of this H\&S lapse on study sites and derive a proportion in order to show its occurrence with regard to the pre-structured list. The same approach was used for site observations of technology in Table 6. For example, from Table 6 the average occurrence of mobile handheld devices in the study is:

Observed occurrence of mobile-handheld devices for sites ( $A+B+$ $C+D) /($ number of sites $)=(3+2+2+2) / 4=2.25$ (an average) .

Therefore the observed proportion for "Mobile handheld devices" $=$ The average occurrence/the weighting $(5)=2.25 / 5=0.45$.

Alternatively the sum of observed occurrence of mobile-handheld devices on sites, $(A+B+C+D)=9$, is divided by the sum of possible observations on study sites (sum of weightings for all 4 sites $=5 \times 4=20$ ).

$9 / 20=0.45$ 
Using the weighting approach described here, a ranking system was then generated as part of each table. Table 5 presents a quantised version of observed categories of lapses, weighted according to Table 2. Similarity in the occurrence of lapses across the four sites was more evident in the area of information management and communication. Up to half of lapses in the criteria (6/12) were observed at $\geq 50 \%$ occurrence on all sites.

Table 5. Quantised Data on Categories of Lapses Observed on Case Study Sites

\begin{tabular}{|c|c|c|c|c|c|c|c|}
\hline $\begin{array}{l}\text { Sub-Category } \\
\text { of Lapses }\end{array}$ & $\begin{array}{l}\text { Maximum Weight } \\
\text { Per Sub-Category } \\
\text { (Number of } \\
\text { Individual Lapses) }\end{array}$ & Site A & Site B & Site C & Site $D$ & $\begin{array}{l}\text { Proportion } \\
\text { of Weighting } \\
\text { Observed }\end{array}$ & $\begin{array}{l}\text { Ranking of } \\
\text { Observed } \\
\text { Occurrence }\end{array}$ \\
\hline PPC kits & 3 & 1 & 1 & 1 & 1 & 0.33 & 3 \\
\hline Handling & 3 & 1 & 1 & 1 & 1 & 0.33 & 3 \\
\hline Behaviour & 6 & 1 & 3 & 2 & 1 & 0.29 & 2 \\
\hline Posture & 8 & 6 & 8 & 7 & 5 & 0.81 & 8 \\
\hline $\begin{array}{l}\text { Vehicular } \\
\text { equipment }\end{array}$ & 3 & 1 & 1 & 1 & 1 & 0.33 & 3 \\
\hline $\begin{array}{l}\text { Material at } \\
\text { workface }\end{array}$ & 5 & 2 & 3 & 4 & 1 & 0.50 & 5 \\
\hline $\begin{array}{l}\text { Material at } \\
\text { staging area }\end{array}$ & 4 & 1 & 2 & 3 & 1 & 0.44 & 4 \\
\hline $\begin{array}{l}\text { Material at } \\
\text { storage }\end{array}$ & 4 & 1 & 1 & 3 & 4 & 0.56 & 6 \\
\hline Material in transit & 2 & - & - & 1 & - & 0.13 & 1 \\
\hline $\begin{array}{l}\text { Communication } \\
\text { quality }\end{array}$ & 3 & 2 & 3 & 2 & 2 & 0.75 & 7 \\
\hline $\begin{array}{l}\text { Information } \\
\text { quality }\end{array}$ & 3 & 3 & 3 & 3 & 3 & 1.00 & 9 \\
\hline $\begin{array}{l}\text { Real time } \\
\text { capacity }\end{array}$ & 6 & 6 & 6 & 6 & 6 & 1.00 & 9 \\
\hline
\end{tabular}

Table 6 presents a quantised version of observed categories of technologies, weighted according to Table 3 and compared to occurrence of lapses in CSM. Occurrence of technology was appreciably low at all four sites, at $<50 \%$ of the criteria. Considering Tables 5 and 6 , Site $\mathrm{C}$ recorded most observations of technology occurrence and the highest aggregate percentage value of shortcomings (lapses). Considering individual categories of shortcomings, Site B has the highest occurrence of lapses in the sub-categories investigated and the least observed technology occurrence. Generally, there was a low occurrence of wireless technologies on all sites, with a high occurrence of information-related lapses. 
Table 6. Quantised Data of ICT Occurrence on Study Sites

\begin{tabular}{|c|c|c|c|c|c|c|c|}
\hline $\begin{array}{l}\text { Sub-Category of } \\
\text { Lapses }\end{array}$ & $\begin{array}{l}\text { Maximum Weight } \\
\text { (Number of ICT } \\
\text { Sub-Groups) }\end{array}$ & Site A & Site B & Site C & Site D & $\begin{array}{l}\text { Proportion } \\
\text { of Weighting } \\
\text { Observed }\end{array}$ & $\begin{array}{l}\text { Ranking of } \\
\text { Observed } \\
\text { Occurrence }\end{array}$ \\
\hline $\begin{array}{l}\text { Mobile handheld } \\
\text { devices }\end{array}$ & 5 & 3 & 2 & 2 & 2 & 0.45 & 5 \\
\hline $\begin{array}{l}\text { Geo-surveillance } \\
\text { instruments }\end{array}$ & 4 & - & - & 3 & 1 & 0.25 & 3 \\
\hline Sensors and scanners & 8 & 1 & 1 & 4 & 2 & 0.25 & 4 \\
\hline Hybrid technologies & 9 & - & - & - & - & 0.00 & 1 \\
\hline $\begin{array}{l}\text { Wireless applications } \\
\text { and services }\end{array}$ & 8 & 3 & 1 & 2 & 1 & 0.22 & 2 \\
\hline
\end{tabular}

Table 7 uses the rankings generated in Tables 5 and 6, respectively, to compare the observed occurrence of specific lapses with the observed occurrence of relevant technologies. To perform this simple correlation we further group the variables under each set of observations into least observed, more observed and most observed. Note that this weighting and measurement is relative to the four case study sites, using the simple numerical strength of their proportions, as explained in the preceding section.

Table 7. Comparison of the Occurrence of CSM Lapses and ICT Categories on Study Sites

\begin{tabular}{lll}
\hline Rank Order & ICT by Ranking of Occurrence & Lapses by Ranking of Severity \\
\hline Most observed & Mobile handheld devices & $\begin{array}{l}\text { Real time capacity } \\
\text { Information quality }\end{array}$ \\
& Sensors and scanners & Posture \\
& & Communication quality \\
More observed & Geo-surveillance instruments & Material at storage \\
& & Material at workface \\
Least observed & Wireless applications and services & Material at staging area \\
& & Vehicular equipment \\
& Hybrid technologies & Handling \\
& & PPC kits \\
& & Behaviour \\
& & Material in transit \\
\hline
\end{tabular}

In Table 7, relatively least observations of technologies correlated with relatively most observations of lapses on site. Low observation of wireless and hybrid technologies correlated with relatively higher observation of information related lapses on site. However, relatively high occurrence of mobile/handheld devices was observed on site, together with relatively high occurrence of lapses in real-time capacity and information and communication quality. 


\section{DISCUSSION}

From results of data analysis, findings suggest poor utilisation of available technology across all four sites with observed managerial lapses constituting process need areas that could benefit from exploitation of potential in available technology. Firstly occurrence of lapses observed on case study sites point to management blind spots, which confirm the existence of human limits in CSM. On case study sites, inventory was marginally automated and only in relation to external logistics. Considerable amounts of materials were stocked, seemingly beyond what would be reasonably depleted within a work period. Secondly it was challenging for CSM to monitor H\&S issues in every area of site simultaneously. Findings also confirm poor utilisation of technology on case study sites. This is evidenced by appreciable occurrence of lapses on site, alongside poor ICT utilisation. The assertion is most exemplified by observations on site B. With reference to the context of South Africa, the study also suggests that CSM could benefit from increased exploitation of technology. Findings are supported by historical and recent literature such as Kim et al. (2013), Lin et al. (2014), Han and GolparvarFard (2015), Akhavian and Behzadan (2016), Hwanga and Leeb (2017), Awolusia, Marksb and Hallowell (2017), Fang et al. (2018) and Dong et al. (2018).

Relevant technologies may also serve as potential mitigation against management lapses, including (1) dependence on periodic information on site status from various nodes and the need for pre-emptive and predictive oversight of site activities and resources (Ozumba and Shakantu, 2008; Akhavian and Behzadan, 2016; Lee et al., 2017), (2) poor supervisor awareness of H\&S infringements and incidents which go unreported (Kelm et al., 2013; Arslan et al., 2014; Aryal et al., 2017; Fang et al., 2018), (3) poor identification of site participants in issuance of materials and equipment (Ozumba and Shakantu, 2008; Wang et al., 2014; Han and GolparvarFard, 2015), (4) poor security and tracking of materials movement and storage on site (Razavi et al., 2012; Han and Golparvar-Fard, 2015) and (5) lack of real-time pervasive and comprehensive knowledge of site status (Ozumba and Shakantu, 2008; Wang et al., 2014; Omar and Nehdi, 2016). Such shortcomings seem regular on site, from the case study observations. Findings of lapses in the study support literature (Green, 1998; Serpell and Alarcon, 1998; González et al., 201 1; Thomas et al., 2005), which substantiate the existence of constraints in CSM. SM process lapses identified from the study, constitute areas which could benefit from infusion of technology, as substantiated by authors including: Lin et al. (2014) and Fang et al. (2018) on H\&S inspection, Razavi et al. (2012), Han and Golparvar-Fard (2015) and Park and Brilakis (2016) on materials monitoring, Tsai, Yang and Lin (2007) and Omar and Nehdi (2016) on data collection and Kim et al. (2013), Braun et al. (2015) and Kang et al. (2016) on-site and general construction management.

Drawing from Ozumba and Shakantu (2014), it is arguable that levels of ICT knowledge among SM personnel and their attitudes toward such technologies may be a major causative factor for the low occurrence of relevant technologies in the study. For example, there is a sharp contrast between occurrence of ICT and high occurrence of lapses on Site C. Observations of sub-optimal adoption also suggest that there is poor awareness of proper implementation requirements and existing possibilities in recent technologies. From a purely TAM perspective (Shore et al., 2018; Taherdoost, 2018), there is an explanation for the occurrence and utilisation of some technologies on sites visited and the relatively lower occurrence of lapses 
in the CSM areas of focus. The behaviour of technology adoption and usage would follow a perceived need and usage capacity in the technology, supported by ease of use and moderated by intention to adopt. However results of the case study do not follow the TAM model uniformly.

Rogers, Singhal and Quinlan (2006) assert that a mental process is involved in the decision to adopt. This notion is supported by Ajzen and Fishbein's theory of reasoned action (TRA) (Özer and Yilmaz, 2011; Ameen and Willis, 2018) and Ajzen's theory of planned behaviour (TPB) (Rosenthal, 2018; Ameen and Willis, 2018). Both theoretical explanations assert the preceding mental processes of actions and patterns of actions and responses, which are backed by decisions. This consideration allows for other internal and environmental factors which influence the intention to adopt. While many of the possible influencing factors would fall outside the purview of the current study, the findings hint at the possible existence of such factors.

Drawing from conclusions in Ozumba and Shakantu (2014), it is further argued that awareness and knowledge of technology could potentially facilitate the cognitive connection among key project stakeholders, with the relationship between perceived needs and functionality of available technology. Literature has advanced mental processes as one of the drivers for technology adoption (De Guinea and Markus, 2009; Singh and Holmström, 2015). This will suggest that there are preceding cognitive processes of actions and responses which inform adoption decisions. Therefore, controlling for other exigencies and considering observed lapses, a relatively higher level of technology utilisation should be expected from the case study sites. Essentially the existence of management lapses should give rise to more technology infusion. However this was not the result from the case study. It is also particularly interesting to note that lapses still occurred with infusion of relevant technology, in the case study. This dynamic suggests that occurrence of technology on site does not translate to utilisation in CSM. The results also suggests the phenomenon of adoption with minimal or no utilisation. It could be that some lag between adoption and utilisation exists in the CSM scenario, as opposed to the operative's scenario, where an artefact of technology is required to execute a work package.

In line with the notion of internal and external influencing factors, the UTAUT (Ameen and Willis, 2018), highlights the key determinant of "facilitating conditions". These are described as perceived organisational support for change, which is moderated by the degree of the voluntariness of use, of the technology. In a construction site scenario and especially the CSM, use of technology for work would generally need organisational support, which would determine technology occurrence to a large extent. However once technology is adopted, voluntariness of use would most probably vary, depending on size, usage, delicacy, cost and strategic nature of the technology. Nevertheless, it would be difficult to disregard any technology if the knowledge and skills are present and a need occurs for which the technology is relevant. So, the apparent phenomenon of technology occurrence and persistent CSM lapses needs to be further explored. From the perspective of the five-stage technology transfer model (Cooper and Zmud, 1990; Ameen and Willis, 2018), technology essentially goes through a process before ending at infusion. At the infusion stage, there is continuous assimilation of the technology in to an organisation's core, culture, processes and practices, which yields structural effectiveness. Taking this view, CSM can be described as an organisational event that is performed by individual actors. Therefore, the technology occurrence 
observed on case study sites may be subject to process stages, thereby delaying appreciable depth of infusion at the time of observation. A full understanding of the dynamics of the wide spectrum of inhibiting factors is beyond the scope of the current article. However, Ozumba and Shakantu (2018) present a detailed exploration of inhibiting factors to technology infusion in CSM and various frames for classifying them.

\section{CONCLUSION}

The objective of the study was to explore process need areas and technology utilisation in CSM. South Africa was used as context for field data collection. Three fundamental areas identified are: CSM, lapses and technology use and infusion of technology and utilisation. The study explored the need and requirements for improving managerial capacity for responsibility; by suitable, appropriate and adequate enhancement, via technology infusion. Findings here form an appropriate basis for building relevant knowledge on ICT and automation technologies in CSM. The study is most relevant in the exploration of process need areas and their linkage with current levels of technology adoption to address such needs.

Findings strongly suggest appreciable occurrence of CSM constrains linked to evidence of human limitations. There is also a strong indication of sub-optimal adoption of technology for CSM on study sites. From the study there is an indication of the possible difference between available technology potential for process enhancement and the extent to which such potential is exploited in CSM. The results also seem to suggest that increased exploitation of available technology potential would impact the occurrence of SM lapses. The suggested link between poor occurrence of wireless application technologies and high occurrence of information-related lapses on all sites supports the last deduction.

The findings highlight gaps that may only be properly identified in technology infusion studies when taking a management perspective and when considering particular contexts. It provides a management-centred view for exploring technology infusion issues, by addressing a management problem in technology infusion, instead of popular application-centred studies that are focused on a single technology. The concept of "process need areas" is introduced, which fuses emergent constructs in Ozumba and Shakantu (2008; 2009). This perspective on management in terms of technology infusion, as opposed to operational needs, sheds light on the impact of human limitations in management. It offers a different perspective for consequent management lapses, conceptualising them as "process need areas" that require technology-based enhancement. Possible challenges to management, in other contexts, where there are appreciable levels of dynamism and volatility are highlighted. In particular, it relates to human and material resources management, within project-based organisational work environments. The main implications of the findings from the current study are that while technology infusion may be popular in discourse on improving operations, findings suggest a major need to enhance management processes. This further implies that a specific focus needs to be given to understand the dynamics of the SM process, in view of the realities of contemporary construction site, increasing SM responsibility and persistent human limitations. The results suggest the need to develop frameworks for technology requirements of projects and their CSM, analysis of possible CSM process needs 
and potential in available technology for specific project management contexts. Results also suggest the need for knowledge capture on the patterns of technology adoption/adaptation in specific SM scenarios. Such knowledge would assist decisions for future projects.

In terms of contributions, the findings arguably offer general points of guidance for infusion of technology in CSM in developing countries such as South Africa. It also contributes to knowledge about diverse trajectories of technologydriven performance in CSM. Existing studies discussed in this article mostly explore relevant technology for highlighted CSM constraints. However, a gap remains in the on-site perspective of process need areas and technology infusion, which focus specifically on SM, instead of operatives or applications. The identified gap has been explored through the on-site perspective, to highlight significant patterns and co-occurrences involving technology infusion and CSM constraints. In addition, the specific emphasis on process need areas in the study shed more light on the dynamics of human limitations in CSM and the interplay of awareness and knowledge and perceived needs and technology adoption, within CSM. Thus, where hitherto such information was mostly implicit, the current study provides a more explicit basis for future studies and stronger extrapolation to other developing country contexts and specifically to South Africa at the national level.

In conclusion, while making the above mentioned contributions, the current study is limited in scope to only four sites, the Johannesburg-Pretoria geographical setting and the time frame utilised to study the cases. As such there is a limitation in the generalisability of results, to the wider South Africa. However the research had a good spread in terms of the number of ICT types or sub-groups, number of possible lapses, age range of people on site and the diversity of roles, participants and languages spoken on each site. The current results therefore set a baseline for the study of process need areas in relation to technology infusion. Considering the scope and limitations of the current article, future studies may increase the number of cases and time frame and employ the survey strategy for wider reach and numerical strength and use focus group for richer empirical evidence. It would be beneficial to compare the results against CSM lapses and technology use in more developed countries and in construction projects with considerable international presence.

\section{REFERENCES}

Abbasian-Hosseini, S., Hsiang, S., Leming, M. and Liu, M. (2014). From social network to data envelopment analysis: Identifying benchmarks at the site management level. ASCE Journal of Construction Engineering and Management, 140(8): 04014028. https://doi.org/10.1061/(ASCE)CO.1943-7862.0000875.

Ahn, Y., Kwak, Y. and Suk, S. (2015). Contractors' transformation strategies for adopting building information modeling. ASCE Journal of Management in Engineering, 32(1): 05015005. https://doi.org/10.1061/(ASCE)ME.19435479.0000390

Aje, I.O., Oladinrin, T.O. and Nwaole, A.N.C. (2016). Factors influencing success rate of contractors in competitive bidding for construction works in SouthEast, Nigeria. Journal of Construction in Developing Countries, 21 (1): 19-34. https://doi.org/10.21315/jcdc2016.21.1.2. 
Ajzen, I. (1991). Perceived behavioral control, self-efficacy, locus of control and the theory of planned behavior. Journal of Applied Social Psychology, 32(4): 665683. https://doi.org/10.1111/j.1559-1816.2002.tb00236.x.

(2011). The theory of planned behaviour: Reactions and reflections. Psychology and Health, 26(9): 1113-1127. https://doi.org/10.1080/08870446. 2011.613995.

Akhavian, R. and Behzadan, A.H. (2016). Smartphone-based construction workers' activity recognition and classification. Automation in Construction, 71: 198209. https://doi.org/10.1016/j.autcon.2016.08.015.

Aljassmi, H. and Han, S. (2014). Classification and occurrence of defective acts in residential construction projects. Journal of Civil Engineering and Management, 20(2): 175-185. https://doi.org/10.3846/13923730.2013.801885.

Ameen, N. and Willis, R. (2018). An analysis of the moderating effect of age on smartphone adoption and use in the united Arab Emirates. Social Transformation: Proceedings of the 23rd UK Academy for Information Systems (UKAIS) International Conference. Oxford: UKAIS.

Arslan, M., Riaz, Z., Kiani, A.K. and Azhar, S. (2014). Real-time environmental monitoring, visualization and notification system for construction H\&S management. ITcon, 19: 72-91.

Aryal, A., Ghahramani, A. and Becerik-Gerber, B. (2017). Monitoring fatigue in construction workers using physiological measurements. Automation in Construction, 82: 154-165. https://doi.org/10.1016/j.autcon.2017.03.003.

Awolusia, I., Marksb, E. and Hallowell, M. (2018). Wearable technology for personalized construction safety monitoring and trending: Review of applicable devices. Automation in Construction, 85: 96-106. https://doi. org/10.1016/j.autcon.2017.10.010.

Barratt, M., Choi, T. and Li, M. (2011). Qualitative case studies in operations management: Trends, research outcomes and future research implications. Journal of Operations Management, 29(4): 329-342. https://doi.org/10.1016/j. jom.2010.06.002.

Beardsworth, A., Keil, E., Bresnen, M. and Bryman, A. (1988). Management, transience and subcontracting: The case of the construction site. Journal of Management Studies, 25(6): 603-625. https://doi.org/10.1111/j.1467-6486.1988.tb00049.x.

Becerik-Gerber, B., KU, K. and Jazizadeh, F. (2012). BIM-enabled virtual and collaborative construction engineering and management. ASCE Journal of Professional Issues in Engineering Education and Practice, 138(3): 234-245. https://doi.org/10.1061/(ASCE)El.1943-5541.0000098.

Bitner, M., Brown, S. and Meuter, M. (2000). Technology infusion in service encounters. Journal of the Academy of Marketing Science, 28(1): 138-149. https://doi. org/10.1177/0092070300281013.

Booth, R. and Lee, T. (1995). The role of human factors and safety culture in safety management. Proceedings of the Institution of Mechanical Engineers, Part B: Journal of Engineering Manufacture, 209(5): 393-400. https://doi.org/10.1243/PIME_PROC_1995_209_098_02.

Braun, A., Tuttas, S., Borrmann, A. and Stilla, U. (2015). A concept for automated construction progress monitoring using BIM-based geometric constraints and photogrammetric point clouds. ITcon, 20: 68-79. 
Bresnen, M., Bryman, A., Ford, J., Keil, E., Beardsworth, A., Jepson, M. and Wray, K. (1984). Effective construction site management: A review. ASCE Journal of Construction Engineering and Management, 110(4): 420-436. https://doi. org/10.1061/(ASCE)0733-9364(1984)110:4(420).

Bryde, D., Broquetas, M. and Volm, J. (2013). The project benefits of Building Information Modelling (BIM). International Journal of Project Management, 31 (7): 971-980. https://doi.org/10.1016/j.ijproman.2012.12.001.

Chae, H., Koh, C. and Prybutok, V. (2014). Information technology capability and firm performance: Contradictory findings and their possible causes. MIS Quarterly, 38(1): 305-326. https://doi.org/10.25300/MISQ/2014/38.1.14.

Chege, L.W., Coetzee, G. and Malachi, J. (2001). e-Commerce and value chain management: The prospects and challenges for the South African construction industry. Proceedings of CIB-W78 International Conference IT in Construction in Africa. Pretoria, South Africa: CSIR, Division of Building and Construction Technology.

Cheng, T. and Teizer, J. (2013). Real-time resource location data collection and visualization technology for construction safety and activity monitoring applications. Automation in Construction, 34: 3-15. https://doi.org/10.1016/j. autcon.2012.10.017.

Chileshe, N., Rameezdeen, R., Hosseini, R., Lehmann, S. and Udeaja, C. (2016). Analysis of reverse logistics implementation practices by South Australian construction organisations. International Journal of Operations and Production Management, 36(3): 332-356. https://doi.org/10.1 108/IJOPM-01-2014-0024.

Construction Industry Development Board (CIDB) (2015). Application for contractor registration. Available at: http://www.cidb.org.za/publications/Documents/ app_form_registration_grade_\%202_9_july_2015.pdf [Accessed on 29 January 2016].

Cooper, R.B. and Zmud, R.W. (1990). Information technology implementation research: A technological diffusion approach. Management Science, 36(2): 123-139. https://doi.org/10.1287/mnsc.36.2.123.

Davis, K. (2013). Different stakeholder groups and their perceptions of project success. International Journal of Project Management, 32(2): 189-201. https://doi.org/10.1016/j.ijproman.2013.02.006.

De Guinea, A. and Markus, M. (2009). Why break the habit of a lifetime? Rethinking the roles of intention, habit and emotion in continuing information technology use. MIS Quarterly, 33(3): 433-444. https://doi.org/10.2307/20650303.

Dong, C., Li, H., Luo, X., Ding, L., Seibert, J. and Luo, H. (2018). Proactive struckby risk detection with movement patterns and randomness. Automation in Construction, 91: 246-255. https://doi.org/10.1016/j.autcon.2018.03.021.

Easterby-Smith, M. (2011). Management Research. 4th Ed. Thousand Oaks, CA: Sage Publications Inc.

Eisenhardt, K. (1989). Building theories from case study research. Academy of Management Review, 14(4): 532-550. https://doi.org/10.5465/ amr.1989.4308385.

Enegbuma, W.I., Aliagha, G.U., Ali, K.N. and Badiru, Y.Y. (2016). Confirmatory strategic information technology implementation for building information modelling adoption model. Journal of Construction in Developing Countries, 21(2): 113-129. 
Fang, Q., Li, H., Luo, X., Ding, L., Luo, H., Rose, T.M. and An, W. (2018). Detecting non-hardhat-use by a deep learning method from far-field surveillance videos. Automation in Construction, 85: 1-9. https://doi.org/10.1016/j. autcon.2017.09.018.

Fang, W., Ding, L., Luo, H. and Love, P.E.D. (2018). Falls from heights: A computer visionbased approach for safety harness detection. Automation in Construction, 91: 53-61. https://doi.org/10.1016/j.autcon.2018.02.018.

Filippini, R. (1997). Operations management research: Some reflections on evolution, models and empirical studies in OM. International Journal of Operations and Production Management, 17(7): 655-670. https://doi. org/10.1108/01443579710175583.

Flynn, B., Sakakibara, S., Schroeder, R., Bates, K. and Flynn, E. (1990). Empirical research methods in operations management. Journal of Operations Management, 9(2): 250-284. https://doi.org/10.1016/0272-6963(90)90098-X.

Garcia, G.J.C., Arditi, D. and Le, K.T. (2014). Construction progress control (CPC) application for smartphone. ITcon, 19: 92-103.

Gatti, U., Schneider, S. and Migliaccio, G. (2014). Physiological condition monitoring of construction workers. Automation in Construction, 44: 227-233. https://doi. org/10.1016/j.autcon.2014.04.013.

González, V., Alarcón, L., Maturana, S. and Bustamante, J. (201 1). Site management of work-in-process buffers to enhance project performance using the reliable commitment model: Case study. ASCE Journal of Construction Engineering and Management, 137(9): 707-715. https://doi.org/10.1061/(ASCE)CO.19437862.0000346

Green, S. (1998). The technocratic totalitarianism of construction process improvement: A critical perspective. Engineering, Construction and Architectural Management, 5(4): 376-386. https://doi.org/10.1046/j.1365232X.1998.54077.x.

Grilo, A. and Jardim-Goncalves, R. (2010). Value proposition on interoperability of BIM and collaborative working environments. Automation in Construction, 19(5): 522-530. https://doi.org/10.1016/j.autcon.2009.11.003.

Grix, J. (2004). The Foundations of Research. London: Palgrave Macmillan.

Guo, H., YU, Y., Xiang, T., Li, H. and Zhang, D. (2017). The availability of wearabledevice-based physical data for the measurement of construction workers' psychological status on site: From the perspective of safety management. Automation in Construction, 82: 207-217. https://doi.org/10.1016/j. autcon.2017.06.001.

Han, K. and Golparvar-Fard, M. (2015). Appearance-based material classification for monitoring of operation-level construction progress using 4D BIM and site photologs. Automation in Construction, 53: 44-57. https://doi.org/10.1016/j. autcon.2015.02.007.

Handfield, R. and Melnyk, S. (1998). The scientific theory-building process: A primer using the case of TQM. Journal of Operations Management, 16(4): 321-339. https://doi.org/10.1016/S0272-6963(98)00017-5.

Hwanga, S. and Leeb, S. (2017). Wristband-type wearable health devices to measure construction workers' physical demands. Automation in Construction, 83: 330-340. https://doi.org/10.1016/j.autcon.2017.06.003.

Ibem, E.O. and Laryea, S. (2014). Survey of digital technologies in procurement of construction projects. Automation in Construction, 46: 11-21. https://doi. org/10.1016/j.autcon.2014.07.003. 
Idoro, G.I. (2011). Effect of mechanisation on occupational health and safety performance in the Nigerian construction industry. Journal of Construction in Developing Countries, 16(2): 27-45.

Kang, L.S., Kim, H.S., Moon, H.S. and Kim, S. (2016). Managing construction schedule by telepresence: Integration of site video feed with an active $\mathrm{nD} C A D$ simulation. Automation in Construction, 68: 32-43. https://doi.org/10.1016/j. autcon.2016.04.003.

Kelm, A., Laußat, L., Meins-Becker, A., Platz, D., Khazaee, M.J., Costin, A.M., Helmus, M. and Teizer, J. (2013). Mobile passive Radio Frequency Identification (RFID) portal for automated and rapid control of Personal Protective Equipment (PPE) on construction sites. Automation in Construction, 36: 38-52. https://doi. org/10.1016/j.autcon.2013.08.009

Ketokivi, M. and Choi, T. (2014). Renaissance of case research as a scientific method. Journal of Operations Management, 32(5): 232-240. https://doi.org/10.1016/j. jom.2014.03.004.

Kim, C., Park, T., Lim, H. and Kim, H. (2013). On-site construction management using mobile computing technology. Automation in Construction, 35: 415-423. https://doi.org/10.1016/j.autcon.2013.05.027.

Kindström, D., Kowalkowski, C. and Sandberg, E. (2013). Enabling service innovation: A dynamic capabilities approach. Journal of Business Research, 66(8): 10631073. https://doi.org/10.1016/j.jbusres.2012.03.003.

Kowalkowski, C., Kindström, D. and Gebaver, H. (2013). ICT as a catalyst for service business orientation. Journal of Business and Industrial Marketing, 28(6): 506513. https://doi.org/10.1108/JBIM-04-2013-0096.

Kozinets, R. (2002). The field behind the screen: Using netnography for marketing research in online communities. Journal of Marketing Research, 39(1): 61-72. https://doi.org/10.1509/jmkr.39.1.61.18935.

Kvale, S. (1996). Interviews: An Introduction to Qualitative Research Interviewing. Thousand Oaks, CA: Sage Publications Inc.

Lai, P.C. (2017). The literature review of technology adoption models and theories for the novelty technology. Journal of Information Systems and Technology Management, 14(1): 21-38. https://doi.org/10.4301/S180717752017000100002.

Lee, J., Park, Y., Choi, C. and Han, C. (2017). BIM-assisted labor productivity measurement method for structural formwork. Automation in Construction, 84: 121-132. https://doi.org/10.1016/j.autcon.2017.08.009.

Lee, W., Lin, K., Seto, E. and Migliaccio, G.C. (2017). Wearable sensors for monitoring on-duty and off-duty worker physiological status and activities in construction. Automation in Construction, 83: 341-353. https://doi.org/10.1016/j. autcon.2017.06.012.

Lin, K., Tsai, M., Gatti, U., Lin, J., Lee, C. and Kang, S. (2014). A user-centered information and communication technology (ICT) tool to improve safety inspections. Automation in Construction, 48: 53-63. https://doi.org/10.1016/j. autcon.2014.08.012.

Love, P., Lopez, R. and Kim, J. (2014). Design error management: Interaction of people, organisation and the project environment in construction. Structure and Infrastructure Engineering, 10(6): 81 1-820. https://doi.org/10.1080/15732 479.2013.767843.

Mead, G. (1938). The Philosophy of the Act. Chicago, IL: University of Chicago Press. 
Meredith, J., Raturi, A., Amoako-Gyampah, K. and Kaplan, B. (1989). Alternative research paradigms in operations. Journal of Operations Management, 8(4): 297-326. https://doi.org/10.1016/0272-6963(89)90033-8.

Miles, M. and Huberman, A. (1984). Qualitative Data Analysis: A Source Book of New Methods. Beverly Hills, CA: Sage Publications Inc.

Mo, Y., Kang, T., Zhang, H., Hong, D. and Lim, M. (2014). Development of 3D camerabased robust bolt-hole detection system for bolting cabin. Automation in Construction, 44: 1-11. https://doi.org/10.1016/j.autcon.2014.03.022.

Mohamed, S. and Anumba, C. (2006). Potential for improving site management practices through knowledge management. Construction Innovation, 6(4): 232-249. https://doi.org/10.1108/14714170610713917.

Mustapha, F. and Naoum, S. (1998). Factors influencing the effectiveness of construction site managers. International Journal of Project Management, 16(1): 1-8. https://doi.org/10.1016/S0263-7863(97)00025-2.

Nassar, N. and AbouRizk, S. (2014). Practical application for integrated performance measurement of construction projects. ASCE Journal of Management in Engineering, 30(6): 04014027. https://doi.org/10.1061/(ASCE)ME.19435479.0000287.

Ofori, G. and Toor, S. (2012). Leadership and construction industry development in developing countries. Journal of Construction in Developing Countries, 17(Supp. 1): 1-21.

Ojiako, U. (2012). Using IS/IT to enhance service delivery. Industrial Management and Data Systems, 112(4): 584-599. https://doi.org/10.1108/02635571211225495.

Ojiako, U., Froise, T., Shakantu, W., Ozumba, A.O., Alasdir, M. and Chipulu, M. (2016). Building Information Modeling (BIM) as a collaborative tool in construction project delivery. Proceedings of UK Academy for Information Systems (UKAIS) Information Systems Comes of Age: 21 Years, Looking Back to Look Forward. Oxford: UKAIS.

Ojiako, U., Maguire, S. and Chipulu, M. (2013). Thematic elements underlying the delivery of services in high-contact public service encounters. Production Planning and Control, 24(6): 532-545. https://doi.org/10.1080/09537287.2011 .642485 .

Omar, T. and Nehdi, M.L. (2016). Data acquisition technologies for construction progress tracking. Automation in Construction, 70: 143-155. https://doi. org/10.1016/j.autcon.2016.06.016.

Özer, G. and Yilmaz, E. (2011). Comparison of the Theory of Reasoned Action and the Theory of Planned Behavior: An application on accountants' information technology usage. African Journal of Business Management, 5(1): 50-58.

Ozumba, A.O.U. (2013). Exploiting the adaptability in information and communication technologies to improve the site management process. PhD diss. Nelson Mandela University.

Ozumba, A.O.U. and Shakantu, W. (2018). Exploring challenges to ICT utilisation in construction site management. Construction Innovation, 18(3): 321-349. https://doi.org/10.1108/Cl-03-2017-0027.

. (2017). Market availability of information and communication technologies and their adoption in site management in South Africa. Association of Schools of Construction of Southern Africa (ASOCSA), The Eleventh Built Environment Conference, Conference Proceedings. Penhill Estate, South Africa: ASOCSA. 
(2014). Exploring the knowledge function in the adoption of ICT in site management in South Africa. Journal of Construction Project Management and Innovation, 4(2): 990-1011.

(2013). Investigating barriers to ICT adoption in site management: A pilot study in South Africa. Paper presented at the RICS COBRA Conference. New Delhi, India, 10-12 September.

. (2012). ICT in site management process: A pilot study in South Africa. RICS COBRA Conference. Las Vegas, USA, 11-13 September.

. (2009). Balancing site information and communication technology systems with available ICT skills. Paper presented at the RICS COBRA Conference. Cape Town, 10-11 September.

. (2008). Achieving ubiquity in the site management process through ICT. Paper presented at the RICS COBRA Conference. Ireland, September.

Park, M. and Brilakis, I. (2016). Continuous localization of construction workers via integration of detection and tracking. Automation in Construction, 72: 129142. https://doi.org/10.1016/j.autcon.2016.08.039.

Parthasarathy, M.K., Murugasan, R. and Murugesan, K. (2017). A critical review of factors affecting manpower and equipment productivity in tall building construction projects. Journal of Construction in Developing Countries, 22(Supp. 1): 1-18. https://doi.org/10.21315/jcdc2017.22.supp1.1.

Parvan, K., Rahmandad, H. and Haghani, A. (2015). Inter-phase feedbacks in construction projects. Journal of Operations Management, 39: 48-62. https://doi.org/10.1016/j.jom.2015.07.005.

Porwal, A. and Hewage, K. (2013). Building Information Modeling (BIM) partnering framework for public construction projects. Automation in Construction, 31: 204-214. https://doi.org/10.1016/j.autcon.2012.12.004.

Rajendran, S., Clarke, B. and Whelan, M. (2013). Contract issues and construction safety management. Professional Safety, 58(9): 56-62.

Razavi, S.N., Montaser, A. and Moselhi, O. (2012). RFID deployment protocols for indoor construction. Construction Innovation, 12(2): 239-258. https://doi. org/10.1108/14714171211215967.

Rogers, E.M., Singhal, A. and Quinlan, M.M. (2006). Diffusion of innovations. In D. Stacks and M. Salwen (eds.), An Integrated Approach to Communication Theory and Research. Oxon, UK: Routledge.

Rosenthal, S. (2018). Procedural information and behavioral control: Longitudinal analysis of the intention-behavior gap in the context of recycling. Recycling, 3(5). https://doi.org/10.3390/recycling3010005.

Rotolo, D., Hicks, D. and Martin, B. (2015). What is an emerging technology? Research Policy, 44(10): 1827-1843. https://doi.org/10.1016/j.respol.2015.06.006.

Serpell, A. and Alarcon, L. (1998). Construction process improvement methodology for construction projects. International Journal of Project Management, 16(4): 215-221. https://doi.org/10.1016/S0263-7863(97)00052-5.

Shore, L., Power, V., de Eyto, A. and O'Sullivan, L.W. (2018). Technology acceptance and user-centred design of assistive exoskeletons for older adults: A commentary. Robotics, 7(1): 3. https://doi.org/10.3390/robotics7010003.

Singh, V. and Holmström, J. (2015). Needs and technology adoption: Observation from BIM experience. Engineering, Construction and Architectural Management, 22(2): 128-150. https://doi.org/10.1108/ECAM-09-2014-0124. 
Singh, V., Gu, N. and Wang, X. (2011). A theoretical framework of a BIM-based multi-disciplinary collaboration platform. Automation in Construction, 20(2): 134-144. https://doi.org/10.1016/j.autcon.2010.09.011.

Stuart, I., McCutcheon, D., Handfield, R., McLachlin, R. and Samson, D. (2002). Effective case research in operations management: A process perspective. Journal of Operations Management, 20(5): 419-433. https://doi.org/10.1016/ S0272-6963(02)00022-0.

Succar, B. (2009). Building Information Modelling framework: A research and delivery foundation for industry stakeholders. Automation in Construction, 18(3): 357375. https://doi.org/10.1016/j.autcon.2008.10.003.

Suh, E., Furst, M., Mihalyov, K. and Weck, O. (2010). Technology infusion for complex systems): A framework and case study. Systems Engineering, 13(2): 186-203. https://doi.org/10.1002/sys.20142.

Taherdoost, H. (2018). A review of technology acceptance and adoption models and theories. Procedia Manufacturing, 22: 960-967. https://doi.org/10.1016/j. promfg.2018.03.137.

Teizer, J. (2015). Wearable, wireless identification sensing platform: Self-Monitoring Alert and Reporting Technology for Hazard Avoidance and Training (SmartHat). ITcon 20: 295-312.

Thomas, A.V. and Sudhakumar, J. (2014). Factors influencing construction labour productivity: An Indian case study. Journal of Construction in Developing Countries, 19(1): 53-68.

Thomas, H., Riley, D. and Messner, J. (2005). Fundamental principles of site material management. ASCE Journal of Construction Engineering and Management, 131 (7): 808-815. https://doi.org/10.1061/(ASCE)0733-9364(2005)131:7(808).

Tsai, M., Yang, J. and Lin, C. (2007). Integrating wireless and speech technologies for synchronous on-site data collection. Automation in Construction, 16(3): 378-391. https://doi.org/10.1016/j.autcon.2006.07.007.

Tushman, M. and Anderson, P. (1986). Technological discontinuities and organizational environments. Administrative Science Quarterly, 31 (3): 439465. https://doi.org/10.2307/2392832.

Vegad, K., Madurwar, M. and Ralegaonkar, R. (2014). Application of AV-ERP system for on-site project monitoring. Construction Innovation, 14(4): 218-531. https://doi.org/10.1108/Cl-01-2014-0007.

Venkatachalam, S. (2015). Analysis of the challenges and implementation strategies on the adoption of building information modelling in South African architectural firms. Journal of Construction, 8(2): 7-12.

Voss, C., Tsikriktsis, N. and Frohlich, M. (2002). Case research in operations management. International Journal of Operations and Production Management, 22(2): 195-219. https://doi.org/10.1108/01443570210414329.

Wang, D., Chen, J., Zhao, D., Dai, F., Zheng, C. and Wu, X. (2017). Monitoring workers' attention and vigilance in construction activities through a wireless and wearable electroencephalography system. Automation in Construction, 82: 122-137. https://doi.org/10.1016/j.autcon.2017.02.001.

Wang, X., Truijens, M., Hou, L., Wang, Y. and Zhou, Y. (2014). Integrating augmented reality with Building Information Modeling: Onsite construction process controlling for liquefied natural gas industry. Automation in Construction, 40: 96-105. https://doi.org/10.1016/j.autcon.2013.12.003.

Weber, M. (1949). The Methodology of the Social Sciences. Glencoe, IL: Free Press. 
Yang, L., O'Connor, J. and Huang, C. (2007). Comparison of technology utilization and benefits in Taiwanese and US industries. ASCE Journal of Management in Engineering, 23(3): 147-155. https://doi.org/10.1061/(ASCE)0742597X(2007)23:3(147).

Yu, Y., Guo, H., Ding, Q., Li, H. and Skitmore, M. (2017). An experimental study of realtime identification of construction workers' unsafe behaviors. Automation in Construction, 82: 193-206. https://doi.org/10.1016/j.autcon.2017.05.002.

Zhong, D., Li, X., Cui, B., Wu, B. and Liu, Y. (2018). Technology and application of real-time compaction quality monitoring for earth-rockfill dam construction in deep narrow valley. Automation in Construction, 90: 23-38. https://doi. org/10.1016/j.autcon.2018.02.024. 